\section{Unlocking children's voices during SARS-CoV-2 coronavirus (COVID-19) pandemic lockdown}

Children have a right to be heard. Involving children in decision-making and development promotes their rights which can make a positive difference locally and globally on issues that matter to them. ${ }^{1}$

The United Nations Convention on the Rights of the Child (UNCRC) defines a child as anyone who has not yet reached their 18th birthday. The UNCRC includes obligations of communities and states to fulfil children's rights ${ }^{2}$ and includes respect for the views of the child (Article 12) and freedom of expression (Article 13). While seeking children's views in a tokenistic fashion is wrong, not seeking their input on the basis that it would be tokenistic is also wrong, but arguably not as wrong as not seeking their views at all. ${ }^{3}$

So, what about during the SARS-CoV-2 (coronavirus) pandemic? This has rapidly become a global phenomenon with hugely significant effects on family life.

Although the clinical course of COVID-19 appears to be much milder in children compared with adults, the other consequences of the pandemic are arguably equally, if not more, damaging to children. It is therefore essential the impact the coronavirus crisis is having on the lives of children and young people is understood. Family members have tragically died. Children have missed out on weeks of in-school education. Social contact between children living in different homes has been decimated. Concerns have arisen about higher levels of abuse. The Children's Commissioner for England has investigated lockdown experiences and government priorities from young people. ${ }^{4}$
Since April 2020 members of the public have been able to submit questions to the UK government for the daily COVID-19 briefing. Astonishingly, the question submission rules specifically prohibit questions from children, blatantly ignoring their rights. An attempt by someone under the age of 18 years to submit a question results in an error message: 'sorry you cannot submit a question. You cannot ask a question in the coronavirus (COVID-19) press conference because you're not old enough.' This stance completely devalues the expertise that children have to bring and silences their voices.

That any reporter or other adult may pose questions (to be answered to one degree or another) but questions from someone on the day before their 18th birthday will not even be considered, is ludicrous and indefensible.

If not because it is their right to be heard; if not because it is the right thing to do; then because the future of society depends on engaged, experienced and enthusiastic children becoming engaged, experienced and enthusiastic adults, it is time for children to have their own COVID-19 questions answered by the UK government. That requires a change in policy so that the prohibition of questions from anyone under the age of 18 years is urgently removed.

We therefore call on child health professionals to add to our demand for change to further promote children's rights during this pandemic now the inequity of the ruling that children cannot be heard has been laid bare. Not allowing children to participate, express their opinions and be heard on matters that affect them is wrong and is a breach of their human rights.

\section{Andrew Rowland $\odot$, 1,2,3 Dianne L Cook ${ }^{1,2,3}$}

${ }^{1}$ School of Health and Society, University of Salford, Salford, UK

${ }^{2}$ Emergency Department, North Manchester General Hospital, Pennine Acute Hospitals NHS Trust,

Manchester, UK

${ }^{3}$ SicKids (a charity registered in England and Wales: 1164131), Manchester, United Kingdom
Correspondence to Professor Andrew Rowland, School of Health and Society, University of Salford, Salford M5 4WT, UK; A.Rowland@salford.ac.uk

Twitter Andrew Rowland @DrAndrewRowland

Contributors Both authors contributed to the drafting of this letter and approved the final version before submission.

Funding The authors have not declared a specific grant for this research from any funding agency in the public, commercial or not-for-profit sectors.

Competing interests None declared.

Patient consent for publication Not required.

Provenance and peer review Not commissioned; externally peer reviewed.

This article is made freely available for use in accordance with BMJ's website terms and conditions for the duration of the covid-19 pandemic or until otherwise determined by BMJ. You may use, download and print the article for any lawful, non-commercial purpose (including text and data mining) provided that all copyright notices and trade marks are retained.

(c) Author(s) (or their employer(s)) 2021. No commercial re-use. See rights and permissions. Published by BMJ.

\section{A) Check for updates}

To cite Rowland A, Cook DL. Arch Dis Child 2021;106:e13.

Accepted 23 June 2020

Published Online First 3 July 2020

Arch Dis Child 2021;106:e13.

doi:10.1136/archdischild-2020-319894

\section{ORCID iD}

Andrew Rowland http://orcid.org/0000-0001-95640032

\section{REFERENCES}

1 George E, Schmidt C, Vella G, et al. Promoting the rights and responsibilities of children: a South Australian example. Glob Health Promot 2017;24:53-7.

2 Lansdown G, Lundy L, Goldhagen J. The U.N. convention on the rights of the child: relevance and application to pediatric clinical bioethics. Perspect Biol Med 2016;58:252-66

3 Lundy L. In defence of tokenism? Implementing children's right to participate in collective decisionmaking. Childhood 2018;25:340-54.

4 Children's Commissioner for England. Lockdown experiences: a group of nine young people told us about their priorities for government. London, UK: Children's Commissioner for England, 2020. https://www.children scommissioner.gov.uk/voices/lockdown-experiencesa-group-of-nine-young-people-told-us-about-theirpriorities-for-government/ 